\title{
Phenolic content and antimicrobial activities of date palm (Phoenix dactylifera $L$.) fruits and leaves
}

\author{
Hajira A. Qadoos ${ }^{1}$, Hend S. Dhafari' ${ }^{1}$, Dalal A. Al Marzooqii ${ }^{1}$, Al-Yzyah I. Yaqoubi', \\ Alagappan Kumarappan ${ }^{2}$, Asiya Nazir ${ }^{1}$, Deena H. Elsori'
}

'Department of Applied Sciences and Mathematics, College of Arts and Science, Abu Dhabi University, P.O Box 59911, Abu Dhabi, United Arab Emirates, ${ }^{2}$ AccuVis Bio, Abu Dhabi, United Arab Emirates

\author{
Received: 26.03.2017 \\ Accepted: 08.04.2017 \\ Published: 12.04 .2017 \\ ${ }^{*}$ Address for \\ correspondence: \\ Dr. Deena Elsori, College \\ of Arts and Science, \\ Abu Dhabi University, \\ P.O Box 59911, Abu Dhabi, \\ United Arab Emirates. \\ E-mail: Deena.elsori@adu. \\ ac.ae
}

\begin{abstract}
This study aimed to investigate total phenolic content and antibacterial activities of different extracts recovered from date palm fruit and leaves using various solvents, including methanol, ethanol, and water. The results showed that the highest phenolic content was found in leaf methanol extract, followed by leaf ethanol extract, and then followed by seed methanol extract $(74.4,67.3$, and $64.7 \mathrm{mg} / \mathrm{g}$, respectively). Whereas the date methanol extract had the lowest phenolic content $(5 \mathrm{mg} / \mathrm{g})$. The study was also scrutinized to find the antibacterial inhibitory property in the leaves and fruits of date palm against four bacterial species (Escherichia coli, Staphylococcus aureus, Bacillus subtilis, and Pseudomonas aeruginosa) using the well-diffusion method and minimum inhibitory concentration (MIC). Date leaves' extracts showed inhibitory effect on the growth of $S$. aureus and B. subtilis and resistance to P. aeruginosa and E. coli. MIC of methanol and ethanol (70\%) leaves' extract was 100 and $250 \mathrm{mg} / \mathrm{ml}$ for $S$. aureus and B. subtilis, respectively; however, all the bacteria have resistance to date fruits' extracts.
\end{abstract}

KEY WORDS: Antimicrobial activity, date palm, minimum inhibitory concentration, phenolic content

\section{INTRODUCTION}

The date palm (Phoenix dactylifera L.), a tropical and subtropical tree, belonging to the family Palmae (Arecaceae) is one of the humankind's oldest cultivated plants. Date palm is the most successful and commercially important crop in the hot-arid regions of the world, for example, Saudi Arabia, Emirates, and Egypt. In these countries, date palm products are commonly used for human and animal consumption, pharmaceuticals, cosmetics, carpentry, and firewood. A large number of date palm cultivars are known; however, until now, only a few of these cultivars have been evaluated for chemical composition and nutritional quality (Chao and Krueger, 2007). Date palm fruits are a good source of vitamins minerals simple carbohydrate and dietary fibers (El-Sohaimy and Hafez, 2010). Pulps of dates hold easily digestible sugars (70\%), mostly glucose, sucrose, and fructose, dietary fibers, and enclose less proteins and fats (Al Farsi and Lee, 2008). Moreover, date fruits possess antioxidant and antimutagenic properties (Vayalil, 2002), attributable to their high levels of polyphenolic compounds and vitamins (Mansouri, et al., 2005; Al-Turki, et al., 2010). The date fruit pulp is rich in phytochemicals such as phenolics, sterols, carotenoids, anthocyanins, procyanins, and flavonoids. The ratio and concentrations of these constituents depend on the type of the fruit, stage of the fruit picking, location, and soil conditions; these phytochemicals also contribute to the nutritional and organoleptic properties of the fruits (Abdul and Alliath, 2008). There was also found a good correlation between the total phenolic content (TPC) and antioxidant activities of the nonvolatile extracts (Faqir et al., 2012). Considering the nutritional importance of dates, studying their biochemical composition and nutritional quality is increasingly being recognized as a worthy and important task. The aim of the present study is to analyze the phenolic profile of date palm fruits and leaves and to evaluate their functional properties such as antioxidant and antimicrobial activities to confirm their nutritional benefits.

\section{MATERIALS AND METHODS}

Date fruits were collected from a date farm in Abu Dhabi, UAE, and brought to the laboratory in sterile containers. Date leaves were collected from a random cultivar in Al Ain city. The used solvents of methanol, ethanol, and ethyl acetate were obtained also from Sigma Company. 


\section{Preparation of Date Palm Tree Fruit and Leaves Extract}

Date fruits were opened, and the seeds were removed. The seedless fruits and leaves were washed with distilled water and kept in the hot oven at $60^{\circ} \mathrm{C}$ for 1 week to dry. Then, the dried fruits and leaves were grinded separately in a blender to make a powder. $10 \mathrm{~g}$ of the grinded date fruits were measured and added to methanol in a conical flask and left in the shaker incubator $150 \mathrm{rpm}$ (rotation/min) for 2 days. On the other hand, $21 \mathrm{~g}$ of the grinded leaves were measured and added to three different solvents, $7 \mathrm{~g}$ each, which are methanol, and ethanol in conical flasks and left in the shaker incubator $150 \mathrm{rpm}$ (rotation/min) for 2 days. The mixture were filtered, poured into a Petri plate, and kept in the oven to dry for 1 week, respectively. The same solvent (methanol) was used to transfer the date extract from the Petri plate to a test tube. The extract was covered with aluminum foil (to avoid oxidation) and stored at the room temperature for the future analysis.

\section{TPC using Spectrophotometer}

TPC of the date palm fruits was determined in extracts using Folin-Ciocalteu assay (El Sohaimy, 2013). To three different concentrations, $0.1,0.3$, and $0.5 \mathrm{ml}$ of crude extract, distilled water was added, respectively, to make it $1 \mathrm{ml}$ and tested for phenolic content separately.

$1 \mathrm{ml}$ of extract was transferred to test tube containing $1 \mathrm{ml}$ of Folin-Ciocalteu reagent followed by addition of $10 \mathrm{ml}$ sodium carbonate $\left(\mathrm{Na}_{2} \mathrm{CO}_{3}\right)(7 \mathrm{~g} / 100 \mathrm{ml}$ the contents were incubated for $5 \mathrm{~min}$ at $50^{\circ} \mathrm{C}$; then, the absorbance was measured at $550 \mathrm{~nm}$ against different concentrations of gallic acid as standard. The phenolic content was expressed as mg gallic acid equivalents per gram of extract (dry weight sample).

\section{Thin Layer Chromatography (TLC)}

TLC was used to separate the extracts compounds to their components. The gallic acid solution was used as a standard. Components of the samples were compared with the standard color using the ultraviolet light hand lamp was adjusted to $302 \mathrm{~nm}$.

\section{Antimicrobial Activity}

The antibacterial activity of the date palm fruit and leave extracts was tested using the agar well-diffusion method against four bacterial species Escherichia coli, Pseudomonas aeruginosa, Bacillus subtilis, and Staphylococcus aureus, which obtained from Accuvis Bio Laboratory, Abu Dhabi University. Holes were punched out from the nutrient agar and the following volumes were added using a micropipette: 75,100 , and $150 \mu \mathrm{l}$. The concentration of the date fruit sample was kept $400 \mathrm{mg} / \mathrm{ml}$ and that of leaf extract was $250 \mathrm{mg} / \mathrm{ml}$. Solvent in which extracts were suspended was used as a negative control; antibiotic amoxicillin was used as a positive control. Then, the diameter of the inhibitory zone for each hole was measured in millimeter using a transparent ruler. The results were analyzed in duplicates and the means values are presented.

\section{Minimum Inhibitory Concentration (MIC)}

The MIC of an antimicrobial agent is the lowest (i.e., minimal) concentration of the antimicrobial agent that inhibits a bacterial isolate from multiplying and producing visible growth. Extracts were prepared in different concentration 100, 250, $400 \mathrm{mg} / \mathrm{ml}$, and added into a sterile tube containing $1 \mathrm{ml}$ of nutrient broth and bacterial cultures were inoculated as 105 cells $/ \mathrm{ml}$ and incubated at $37^{\circ} \mathrm{C}$ for $18-24 \mathrm{~h}$. Controls were incubated like nutrient broth with only extract and another tube with only bacterial cultures. After incubation, results were examined for turbidity in the tubes with control and also to confirm the results, loop of culture was inoculated in agar plates by streaking.

\section{RESULTS}

\section{TPC using Spectrophotometer}

The results in Table 1 showed that both fruit and leaf have phenolic content. The concentration of phenolic content was calculated by the standard curve of gallic acid (Figure 1). Results revealed that the highest phenolic content was found in leaf methanol sample $(74.4 \mathrm{mg} / \mathrm{g})$, followed by leaf ethanol sample $(67.3 \mathrm{mg} / \mathrm{g})$, and followed by seed methanol sample $(64.7 \mathrm{mg} / \mathrm{g})$. On the other hand, the methanol date sample had the lowest phenolic content $(5 \mathrm{mg} / \mathrm{g})$. However, it was observed ethanol and ethyl acetate of date fruit does not showed any result.

\section{TLC}

The result in Figure 2 showed that the closest colors to the standard gallic acid (sample 7) are ethanol leaf (sample 1), methanol leaf (sample 3), and methanol date (sample 5), which indicates that the highest phenolic content exists in the leaf methanol extract, then the leaf ethanol extract, followed by the date methanol extract. However, further studies are required to identify the different types of phenolic compounds exist in the date palm fruits and leaves. This can be done by gas chromatography-mass spectrometry technique. 
Table 1: Phenolic content of date and leaf extracts

\begin{tabular}{|c|c|c|c|c|c|c|c|}
\hline Sample & Concentration (ml) & Quantity (g) & $\begin{array}{c}\text { Extract } \\
\text { volume }(\mathrm{ml})\end{array}$ & Phenol content $\mu \mathrm{g} / \mathrm{ml}$ & Multiplied by $1000(\mu \mathrm{g})$ & Divided by 1000 (mg) & $\begin{array}{c}\text { Phenol } \\
\text { content (mg) }\end{array}$ \\
\hline Date methanol & 0.1 & 10 & 10 & 50.210 & 50210 & 50 & 5 \\
\hline Leaf methanol & 0.1 & 7 & 10 & 521.338 & 521338 & 521 & 74.4 \\
\hline Leaf ethanol & 0.1 & 7 & 10 & 470.860 & 470860 & 471 & 67.3 \\
\hline
\end{tabular}

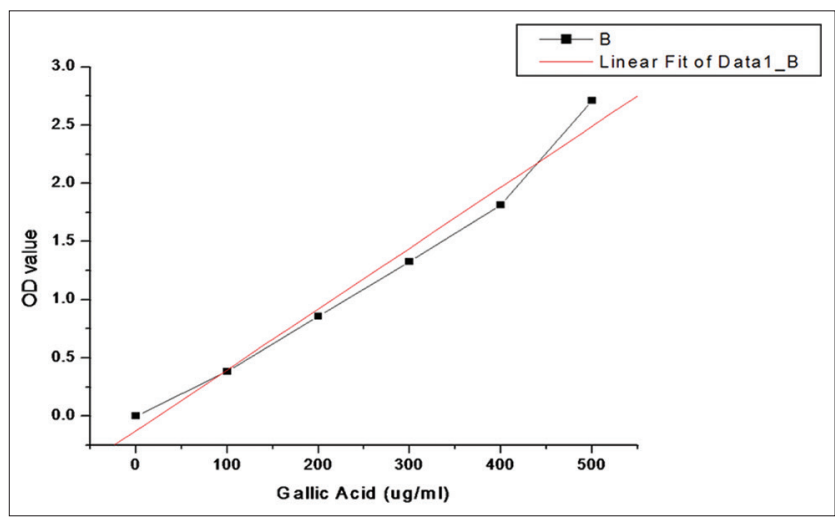

Figure 1: Standard curve of gallic acid

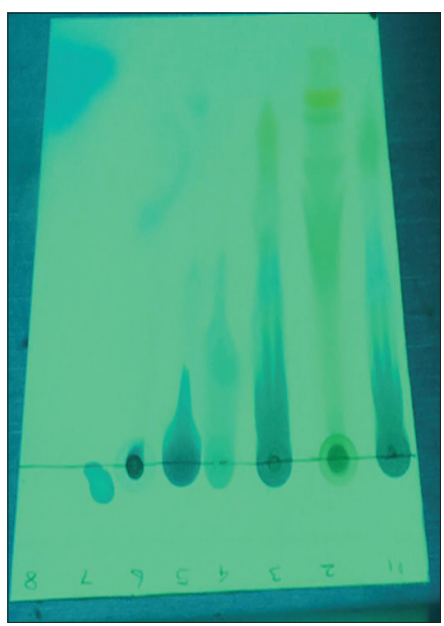

Figure 2: Thin-layer chromatography of date and leaves extracts

\section{Antimicrobial Activity}

The antibacterial activity of date palm fruits extracts of two different solvents (70\% ethanol and methanol) against four bacteria study revealed that date fruit extracts are not capable of inhibiting the growth of Gram-positive and Gram-negative bacteria that are used in this study (Table 2). On the other hand showed the antibacterial activity of date palm leaves extracts isolated by solvents (70\% ethanol and methanol) against four bacterial species E. coli, P. aeruginosa, B. subtilis, and S. aureus (Table 2). Antibiotic amoxicillin was used as positive control for all bacterial strains.

The methanol extract had shown high inhibitory zone against B. subtilis and S. aureus compared to $70 \%$ ethanol
(Figure 3). When the added volume of extract increases, the inhibitory zone increases as well. The highest inhibition zone $(15 \mathrm{~mm})$ was observed against $S$. aureus by the leaf methanol extract.

Among the four bacteria, S. aureus is more sensitive to the leaves extract as it showed the highest inhibitory zone, then B. subtilis came next. On the other hand, both E. coli and $P$. aeruginosa showed resistance against all the leaves extract as no inhibitory zone appeared around the holes in the agar plates (Figures 1 and 2). This means that the Gram-positive bacteria are more sensitive to the leaves extracts than the Gram-negative bacteria.

When compared with the antibiotic (positive control) zone of inhibition, the inhibition zones by the leaf extracts were comparatively less except the methanol leaf extract against the $S$. aureus. The difference between the methanol leaf extract and the antibiotic was $2 \mathrm{~mm} ; 15 \mathrm{~mm}$ by methanol $150 \mu \mathrm{l}, 17 \mathrm{~mm}$ by amoxicillin $50 \mu \mathrm{l}$ against $S$. aureus. The difference between the positive control and B. subtilis was recorded very high.

The antibacterial activity of date and leaves extracts with different solvents (ethanol and methanol) against four strains of bacteria showed that the methanol leaf extract had the highest inhibitory zone against the different bacterial strains, while the date fruits have not shown any inhibitory zone against the different bacterial strains. Because of the high content of carbohydrates found in the date fruits, the phenolic compounds might be wrapped by them. These results approved the strong relationship between the phenolic content and the antibacterial activity.

\section{MIC}

The MIC was conducted to identify the lowest concentration that extract will inhibit the growth of bacteria. This method was done on three bacteria which are B. subtilis, E. coli, and $S$. aureus against three different extract concentration which are 100,250 , and $400 \mathrm{mg} / \mathrm{ml}$ of ethanol and methanol extract. S. aureus showed inhibitory effect for the leaves extracts and at all the different concentrations and its MIC in all the three extract was $100 \mathrm{mg} / \mathrm{ml}$. B. subtilis showed inhibited effect at 250 and $400 \mathrm{mg} / \mathrm{ml}$ of two different 
leaves extracts: Methanol and 70\% ethanol. The MIC for B. subtilis was $250 \mathrm{mg} / \mathrm{ml}$ of ethanol extract and methanol extract. E. coli and P. aeruginosa were strong enough to resist the effect of the leaves extracts concentrations even at high concentration that did not show any inhibitory effect (Table 3).

\section{DISCUSSION}

Our results are in agreement, to some extent, with that reported by Al-Farsi et al., 2005 who found that total phenol contents of dates were in methanol and water extracts, respectively. The present study also proved that the most phenolic content was found in methanol extract.

Date palm leaf extracts showed good inhibitory effect against Gram-positive bacteria. Moreover, our methanol extracts' inhibitory results were in line with the studies of Jaroszynska, 2003 who found that the greatest extraction is done by methanol. The inhibition zone seen by methanol leaf extract ranges from 12 to $15 \mathrm{~mm}$ against $S$. aureus

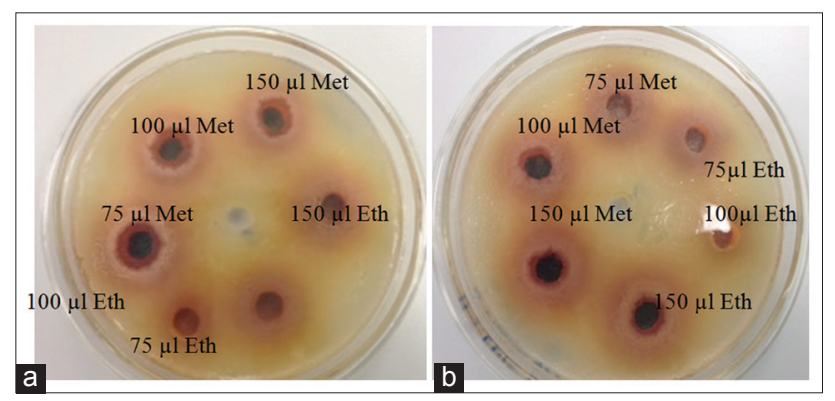

Figure 3: Inhibition zone of bacterial growth using various volumes of date palm leaves $70 \%$ ethanol extracts (a) Staphylococcus aureus, (b) Bacillus subtilis. (Eth denotes ethanol; Met denotes methanol)

Table 2: Antibacterial activity of date palm leaves (Inhibitory zone in $\mathrm{mm}$ )

\begin{tabular}{|c|c|c|c|c|c|c|c|}
\hline \multirow[t]{2}{*}{ Bacteria/volumes } & \multicolumn{3}{|c|}{$70 \%$ ethanol } & \multicolumn{3}{|c|}{ Methanol } & \multirow{2}{*}{$\frac{\text { Amoxicillin }}{50 \mu \mathrm{l}}$} \\
\hline & $75 \mu \mathrm{l}$ & $100 \mu \mathrm{l}$ & $150 \mu \mathrm{l}$ & $75 \mu \mathrm{l}$ & $100 \mu \mathrm{l}$ & $150 \mu \mathrm{l}$ & \\
\hline B. subtilis & 9 & 10 & 10 & 12 & 13 & 13.5 & 40 \\
\hline E. coli & ND & ND & ND & ND & ND & ND & 35 \\
\hline$P$. aeruginosa & ND & ND & ND & ND & ND & ND & 16 \\
\hline S. aureus & 12 & 11 & 13 & 12 & 13.5 & 15 & 17 \\
\hline
\end{tabular}

ND: Not definite, E. coli: Escherichia coli,

S. aureus: Staphylococcus aureus, B. subtilis: Bacillus subtilis,

$P$. aeruginosa: Pseudomonas aeruginosa

Table 3: MIC

\begin{tabular}{lccccccc}
\hline Bacteria & \multicolumn{3}{c}{$70 \%$ ethanol } & & \multicolumn{3}{c}{ Methanol } \\
\cline { 2 - 4 } \cline { 6 - 8 } & 100 & 250 & 400 & & 100 & 250 & 400 \\
\hline B. subtilis & $\mathrm{x}$ & & $\checkmark$ & & $\mathrm{n}$ & $\checkmark$ & $\checkmark$ \\
P. aeruginosa & $\mathrm{x}$ & $\mathrm{x}$ & $\mathrm{x}$ & & $\mathrm{x}$ & $\mathrm{x}$ & $\mathrm{x}$ \\
E. coli & $\mathrm{x}$ & $\mathrm{x}$ & $\mathrm{x}$ & & $\mathrm{x}$ & $\mathrm{x}$ & $\mathrm{x}$ \\
S. aureus & $\checkmark$ & $\checkmark$ & $\checkmark$ & & $\checkmark$ & $\checkmark$ & $\checkmark$ \\
\hline
\end{tabular}

MIC: Minimum inhibitory concentration. $\checkmark$ : Growth, $x$ : Inhibited. which was also similar to the studies done by Al-Diahan and Bhat, 2012. And also, they recorded the inhibition zone for aqueous leaf extract to be $10.5 \mathrm{~mm}$ which was also similar to our inhibitory zone for $S$. aureus, i.e., 9-11 mm. The results of this study give comparatively small inhibitory zone in B. subtilius, i.e., 13.5 where Perveen, et al., 2012 found the methanol extract to give an inhibition zone of $21.3 \mathrm{~mm}$. Therefore, our palm leaf extracts showed inhibitory effect only for Gram-positive bacteria.

Date palm leaves' extracts were further examined to find MIC for B. subtilis and S. aureus. For B. subtilis MIC was found as $250 \mathrm{mg} / \mathrm{ml}$ for ethanol and methanol and for $S$. aureus MIC was $100 \mathrm{mg} / \mathrm{ml}$ for water, ethanol, and methanol.

The leaf extract of the common plant Bixa orellana recorded the MIC against the $S$. aureus and the P. aeruginosa to be 18.88 and $75.54 \mathrm{mg} / \mathrm{ml}$, respectively. The MIC observed by the leaf extract of mango species Mangifera indica against the $S$. aureus was around $75 \mathrm{mg} / \mathrm{ml}$ (Doughari and Manzara, 2008). Relatively, the palm leaf extracts used were in high concentrations for the MIC against bacterial strains.

\section{REFERENCES}

Abdul A, Alliath A. Antioxidant activity of Bahraini date palm (Phoenix dactylifera L.) Fruit of various cultivars. Int J Food Sci Technol 2008;43:1033-40.

Al-Diahan S, Bhat RS. Antibacterial activities of extracts of leaf, fruit, seed and bark of Phoenix dactylifera. Afr J Biotechnol 2012;11:10021-5.

Al-Farsi MA, Lee CY. Nutritional and functional properties of dates: A review. Crit Rev Food Sci Nutr 2008;48:877-87.

Al-Turki S, Shahba MA, Stushnoff C. Diversity of antioxidant properties and phenolic content of date palm (Phoenix dactylifera L.) Fruits as affected by cultivar and location. J Food Agric Environ 2010;8:253-60.

Chao CT, Krueger RR. The date palm (Phoenix dactylifera L.): Overview of biology, uses, and cultivation 2. Hortic Sci 2007;42:1046-311.

Doughari JH, Manzara S. In vitro antibacterial activity of crude leaf extracts of Mangifera indica Linn. Afr J Microbiol Res 2008;2:67-72.

El Sohaimy SA. The effect of cooking on the chemical composition of artichoke (Cynara scolymus L.). Afr J Food Sci Technol 2013;3:182-7.

El-Sohaimy SA, Hafez EE. Biochemical and nutritional characterizations of date palm fruits (Phoenix dactylifera L.). J Appl Sci Res 2010;6:1060-7.

Faqir MA, Sardar IB, Ahmad HE, Muhammad IK, Muhammad N, Shahzad H, et al. Phytochemical characteristics of date 
palm (Phoenix dactylifera) fruit extracts. Pak J Food Sci 2012;22:117-27.

Hertog MG, Kromhout D, Aravanis C, Blackburn H, Buyina R, Fidanza F, et al. Flavonoid intake and long-term risk of coronary heart disease and cancer in the seven countries study. Arch Intern Med 1995;155:381-6.

Hertog MG, Feskens EJ, Hulman PC, Katan MB, Kromhout D. Dietary antioxidant flavonoids and risk of coronary heart disease the Zutphen elderly study. Lancet 1993;342:1007-11.

Jaroszynska J. Influence of solvent choice on the recovery of phytogenic phenolic compounds extracted from plant material. Pol J Environ 2003;12:481-4.

Al-Farsi M, Alasalvar C, Morris A, Baron M, Shahidi F.
Comparison of antioxidant activity, anthocyanins, carotenoids, and phenolics of three native fresh and sundried date (Phoenix dactylifera L.) Varieties grown in Oman. J Agric Food Chem 2005;53:7592-9.

Mansouri A, Embarek G, Kokkalou E, Kefalas P. Phenolic profile and antioxidant activity of the Algerian ripe date palm fruit (Phoenix dactylifera). Food Chem 2005;89:411-20.

Perveen K, Bokhar N, Soliman D. Antibacterial activity of Phoenix dactylifera L. Leaf and pit extracts against selected gram negative and gram positive pathogenic bacteria. J Med Plants Res 2012;6:296-30.

Vayalil PK. Antioxidant and antimutagenic properties of aqueous extract of date fruit (Phoenix dactylifera L. Arecaceae). J Agric Food Chem 2002;50:610-17. 